\title{
Leak Detection using Non-Dispersive Infrared Light Emission on A Hazardous Area Automatically
}

\author{
Kalaiselvi B, Vijayan T, Sridharraja D, Abinethri R
}

\begin{abstract}
This project portrays a programmed oil spill indicator framework. that can pick out coincidental oil leaks.The usage of non-dispersive infrared (NDIR) identification innovation as a motive for an dangerous area characterization is portrayed. techniques for spotting holes utilizing NDIR innovation, evaluating spill records are exactly recognized and expected. The motive for a system dangerous sector association are displayed. Confinements related with the innovation are likewise characterised. there is increasing request to build up a way which can perceive spillage precisely with a low likelihood of fake caution and excessive chance of discovery. A story low variety and minimum attempt spill location framework is created. with the aid of making use of NDIR innovation a version is created and exhibit every single trial end result. high exactness and effective framework on the way to precisely secure watchman sessions ecological risks and financial misfortune. destiny upgrades on this undertakings is a far off sensor machine gazing stage for oil spill discovery. with the aid of utilizing a custom sensor sheets went with calculations to address organize creation, spill interfere on identification giving message through GSM and so on. [1],[ $3],[5]$
\end{abstract}

Keywords : Brain Computer Interface(BCI); Electroencephalogram(EEG);General Terms-Paralysis;Locked in syndrome;

\section{INTRODUCTION}

Non-dispersive Infrared distinguishing development is notably used for the acknowledgment of carbon-based totally definitely gasses and vapors. The advancement has been melded into issue identifying and open way fuel acknowledgment video display units for pretty a while. The improvement has advanced to present a non-stop image of a crook launch spill source. The improvement is used by severa institutions perceive spill assets in working places of work and to signify consistence with air fine regulatory requirements. The NDIR development can be used as a chunk of mixture with severa advances that license a fuel or vapor damage to be assessed. The improvement at that factor offers goal records that may be used as a cause in the again of

Revised Manuscript Received on August 22, 2019.

B.Kalaiselvi, Department of EIE, Bharath Institute of Higher education and research, Tamilnadu, India. Email: kalaiselvi.eie@bharathuniv.ac.in

Sridhar Raja D Department of EIE, Bharath Institute of Higher Education and Research, Tamilnadu, India. Email: sridharraja.eie@bharathuniv.ac.in

T.Vijayan, Department of EIE,Bharath Institute of Higher education and research, Tamilnadu, India. Email: vijayan.eie@bharathuniv.ac.in

R.Abinethri, Department of EIE, Bharath Institute of Higher education and research, Tamilnadu, India. Email: abi.eie@ bharathuniv.ac.in portraying a dangerous range portrayal. The improvement is particularly essential in choosing the diploma of agreeable air go with the flow required to allocate an office department 2 or area 2 the use of the criteria described in API RP 500 and API RP 505. It in like way offers goal criteria to portray a shape in attitude on "running revel in" as delineated in NFPA 497. to apply the development as an explanation in the back of a volatile location request format, a portrayed system need to be used. to use the improvement as an explanation in the lower back of a volatile place request plan, a portrayed technique need to be used. a relentless interpretation of the information won regarding the unsafe zone portrayal industry regulations is needed and what's extra the hindrances of the development were given on. This paper discusses the ones problems and gives a technique that lets in the customer to explain a perilous area direction of movement in mind-set on records got from a NDIR take a look at of an workplace. [2 ],[4],[6]

A chart of a common check gadget used for gearbox oil NDIR examination is showed up in parent 1. A trying out siphon takes oil from the gearbox sump or oil archive, and siphons it thru a test cellular. This reviewing circle is required because of weight and movement requirements. A warmness producer shines broadband IR essentialness thru a check, and a narrowband channel isolates the wavelength of interest, that is recognized the usage of a discoverer in light of one in every of multiple norms. [19],[20],[21] This shape ultimately measures the ingestion at a specific wavelength restricted by way of way of the narrowband channel. An absolute estimation gadget will furthermore compare the ingestion at a control wavelength, to distinguish and that on the wavelength of hobby, which limits temperature affects. this could be cultivated with the aid of both the use of a second test cell with an exclusive narrowband channel, or via the use of using a mechanical system to change among two channels. a few different alternative is to use a ramification of identifiers with considered one of a type narrowband channels, and a single manufacturer [9], besides this calls for a especially based locator, this is an increasing number of applicable for a creation gadget. NDIR-primarily based definitely oil condition looking has been delineated, using both settled times of oil [1] and on line systems wherein oil is siphoned thru a take a look at cell [nine].

In all cases, the thickness of the test (as an example the hole the various .home windows) is spherical zero.1-zero. $2 \mathrm{~mm}$. the relationship among the

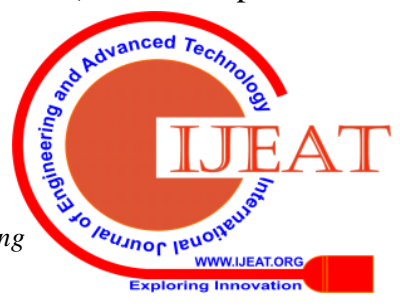


scene IR electricity and the transmitted energy, for an absorption way length is given with the aid of manner of the Lambert-Beer equation[11]:

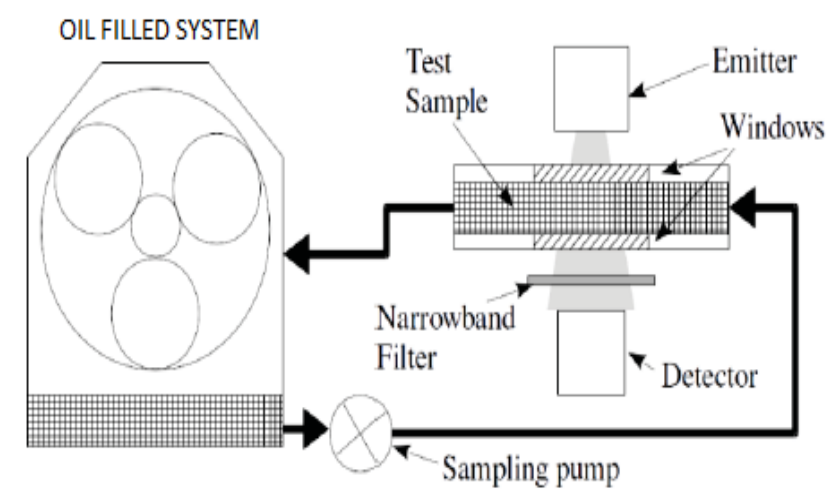

Figure 1.Proposed system based on NDIR monitoring system

various oils can display unmistakable debasement frameworks, provoking differing adjustments in IR protection territory. numerous mulls over on the use of NDIR sensors for oil assessment middle throughout the assessment of engine oils. the ones will in great degrade via oxidation, which turns on prolonged ingestion at wavenumbers from $1690 \mathrm{~cm}-1$ to $1760 \mathrm{~cm}-1$, due to development of blends containing the carbonyl $(\mathrm{C}=\mathrm{O})$ bond $[1,3]$. Phosphate ester water pushed oils degrade thru water ingestion, which could react with the oil. This suggests up inside the area round $3500 \mathrm{~cm}-1$ [nine]. For gearbox oils, oxidation can be impressively an increasing number of unpretentious, particularly with maximum critical constructed oils, and situation checking is based totally upon keeping aside using the oil blanketed substances [12], which can range set up upon the maker and oil mark. as an example, in [12] the diploma of molybdenum inside the device oil, from the antiwear blanketed substance, is bankrupt down using IR spectroscopy. The progressions to the variety are unpretentious and are thusly prohibited for NDIR exam. with the aid of way of getting to know the spectra of the oil when it is new and standing out it from spectra of antique oil, suitable locale of hobby can be perceived for assessment [7]. The FTIR spectra are showed up in determine 2, where the maximum massive distinction is a pinnacle at a wavenumber of $1740 \mathrm{~cm}-1$ which is on the market in new oil yet now not in used oil. This zenith thinks approximately to a carbonyl bond, that can deal with an ester-based totally included substance [three]. notwithstanding the manner that the substance formation of the oil isn't always appeared, and outlandish to get hold of thru the maker, the manner in which that the zenith disappears with oil age recommends that it addresses a further substance this is being depleted, and is henceforth a higher than common contender for estimation[7],[ 9] ,[11]

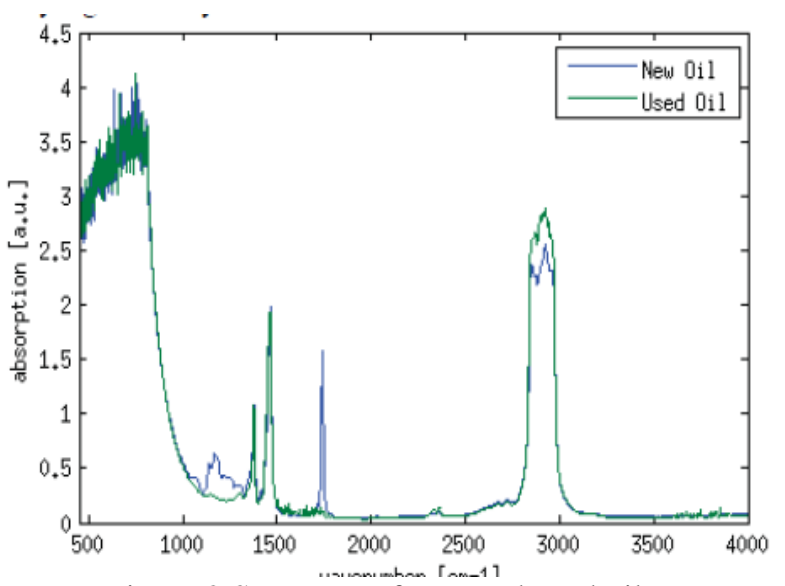

Figure 2 Spectrum of new and used oil FTIR

\section{TeSt Procedures AND ReSUlts}

For the checking out, the check cellular become assembled with the specified range of spacer plates and put in a stack with the manufacturer, identifier and channels. proper at the same time as converting amongst vintage and new oil, inside the check cellular grow to be wiped easy. beginning attempting out changed into finished with a settled speaker get of 100, and with the banner expected using an oscilloscope, inrequest to pick the preferred intensifier grabs for logging with the microcontroller. For this check, the situation of the marker and producer concerning the top and base of the check cell have been kept ordinary, except pastime plan modified into thru eye, that can initiate mistakes inside the effects. [14], [ 16], [18]

A high-quality drawback of this exam is that the manufactured shape of the oil isn't stated, and the conscious apex is thought to be a in addition substance which channels, and the usage of which can advise the need to displace the oil. The fact of the situation might probably prove that the oil is still in reality prepared to play out its capacity with this additional substance depleted. except, the effects are specific to the brand of oil used, with various manufacturers at danger to contain an different included substance percent., attaining special changes to the IR make bigger. Coincidentally, the checks assist the affiliation of averaging the sensor yield over a long time duration as a method for allowing a more hollow gauge in NDIR evaluation of oil, which grows the sound judgment of the usage of NDIR for online evaluation. [8],[ 10] ,[12]

\section{CONCLUSION}

Exams were done to find the achievability of usingNDIR exam to gauge the corruption of the oil in wind oil filled case, using notably large oil hole estimates thanpreviously distinct in writing. The exams are primarily based onestimating the diploma of a draining brought substance, which suggests up asa top at a wavelength of five.seventy four $\mu \mathrm{m}$ in the IR range. The results advise that estimation of the introduced substance intake shouldbe achievable with a $2 \mathrm{~mm}$ hollow length or littler the use of the signal acquisition and making prepared structures depicted here, but with a $3 \mathrm{~mm}$ hole a bizarrely low signal is introduced forreasons now not regarded at this degree. To explore this issuefurther might require

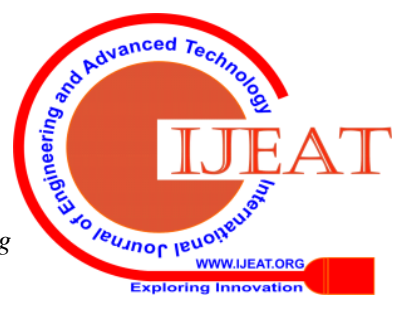


estimations at distinct hollow sizes withinthe enlarge on this exam, that can display whether or not or no longer the 3 mmresult is everyday or following an example not predicted bytheory.For a $3 \mathrm{~mm}$ hole period, a first rate signal is as however perceptible for implemented oil, so it might be potential to evaluate the introduced substance depletionafter some diploma of exhaustion has came about. Be that as it can, withoutknowing the underlying added substance degree this can now not be correct.further paintings may also need to consist of making oil tests with differentadditive levels, via blending vintage and new oil, to test how thesensors distinguish the arduous degrees.A vital obstacle of this studies is that the chemicalcomposition of the oil isn't acknowledged, and the planned top is concept to be an brought substance which drains, and the depletionof which could suggest the want to supplant the oil. it'd bethe case that the oil stays truly organized to play out its functionwith this introduced substance exhausted. moreover, the effects arespecific to the logo of oil applied, with awesome manufacturers probable tocontain an trade delivered substance package deal, coming about in differentchanges to the IR variety. via and with the aid of the usage of, the exams validatethe system of averaging the sensor yield over a protracted timeperiod as a method for allowing a larger hole period in NDIRanalysis of oil, which expands the reasonableness of using NDIRfor online research.. [13], [15],[17]

\section{REFERENCES}

[1] Sharma, R.K., Irusapparajan, G. \& Periyaazhagar, D. 2019 "Three-phase symmetric cascading Z-source seven levels multilevel inverter excited by multi carrier sinusoidal pulse width modulation scheme", International Journal of Innovative Technology and Exploring Engineering, vol. 8, no. 10, pp. 4269-4274

[2] Velavan, R., Bharanidharan, S. \& Sheeba, B. 2019, "EMF pollution Causes, effects and protection", International Journal of Innovative Technology and Exploring Engineering, vol. 8, no. 9 Special Issue 3, pp. 1166-1168.

[3] Saravana, S., Balaji, S., Arulselvi, S. \& John Paul Praveen, A. 2019, "Reliable power quality monitoring and protection system", International Journal of Innovative Technology and Exploring Engineering, vol. 8, no. 9 Special Issue 3, pp. 644-645.

[4] Tamil Selvan, S. \& Sundararajan, M. 2019, "Performance Parameters of 3 Value 8t Cntfet Based Sram Cell Design Using H-Spice", International Journal of Recent Technology and Engineering, vol. 8, no. 2 Special issue 5, pp. 22-27.

[5] Jac Fredo, A.R., Abilash, R.S., Femi, R., Mythili, A. \& Kumar, C.S 2019, "Classification of damages in composite images using Zernike moments and support vector machines", Composites Part B: Engineering, vol. 168, pp. 77-86.

[6] Kathiravan, P. \& Govindaraju, C. 2019, "Design and evaluation of ultra gain isolated DC-DC converter for photovoltaic system", International Journal of Engineering and Advanced Technology, vol. 8, no. 5, pp. 2646-2651.

[7] Kripa, N., Vasuki, R. \& Kishore Kanna, R. 2019, "Realtime neural interface controlled au-pair BIMA bot", International Journal of Recent Technology and Engineering, vol. 8, no. 1, pp. 992-994.

[8] Mohanraj, Meenaa Kumari, M., Philomina, S. \& Jasmin, M. 2019 , "In-situ humidity measurement of hydrogen fuel cell car using MEMS sensor", International Journal of Recent Technology and Engineering, vol. 8 , no. 1 , pp. 41-43.

[9] Velmurugan, T. \& Prakash, S. 2019, "Artificial intelligent based distribution automation of swift fault detection isolation and power restoration for HT network", International Journal of Innovative Technology and Exploring Engineering, vol. 8, no. 6, pp. 1-6.

[10] Dwarakesh, K. \& Prem Kumar, G. 2019, "Five-level inverter based sequential boost system using fuzzy logic controller", International Journal of Innovative Technology and Exploring Engineering, vol. 8, no. 6, pp. 12-19.
[11] Anne Gifta, A. \& Hemavathi, G. 2019, "Analysis of grid tied solar PV system using ANFIS Algorithm", International Journal of Innovative Technology and Exploring Engineering, vol. 8, no. 6, pp. 312-316.

[12] Jayavel, R., Rangaswamy, T.R. \& Prakash, S. 2019, "Efficient grid management system with renewable and conventional power sources", International Journal of Innovative Technology and Exploring Engineering, vol. 8, no. 6, pp. 287-289.

[13] Hemavathi, G. \& Maheshwaran, S. 2019, "Proportional resonant controlled high gain step-up converter system with improved response", International Journal of Innovative Technology and Exploring Engineering, vol. 8, no. 6, pp. 317-323.

[14] Periyaazhagar, D. \& Irusapparajan, G. 2019, "Design and completion of asymmetric single phase 27 level cascaded mli for various pwm scheme", International Journal of Innovative Technology and Exploring Engineering, vol. 8, no. 6, pp. 792-797.

[15] Mahalakshmi, V. \& Vijayaragavan, S.P. 2019, "PV based power electronic converters for high voltage DC applications", International Journal of Recent Technology and Engineering, vol. 7, no. 6, pp. 670-674.

[16] Irusapparajan, G., Periyaazhagar, D., Prabaharan, N. \& Rini Ann Jerin, A. 2019, "Experimental verification of trinary DC source cascaded h-bridge multilevel inverter using unipolar pulse width modulation", Automatika, vol. 60, no. 1, pp. 19-27.

[17] Sangeetha, G., Sherine, S., Arputharaju, K. \& Prakash, S. 2019, "On Line Monitoring of Higher Rated Alternator using Automated Generator Capability Curve Administer", Proceedings of the IEEE International Conference on \&amp;quot;Recent Trends in Electrical, Control and Communication\&amp;quot;, RTECC 2018, pp. 176.

[18] Bycil, V.J. \& Wiselin, M.C.J. 2019, "Modeling and analysis of vibration energy harvesting system using piezo stack", International Journal of Mechanical and Production Engineering Research and Development, vol. 9, no. Special Issue 1, pp. 523-533.

[19] Sripada, A., Warrier, A., Kapoor, A., Gaur, H. \& Hemalatha, B. 2018 , "Dynamic lateral balance of humanoid robots on unstable surfaces", International Conference on Electrical, Electronics, Communication Computer Technologies and Optimization Techniques, ICEECCOT 2017, pp. 539.

[20] Srinivasan, S., Thirumalaivasan, K. \& Sivakumaran, T.S. 2018 , "Performance evaluation of double-output luo converters", Journal of Advanced Research in Dynamical and Control Systems, vol. 10, no. 10 Special Issue, pp. 870-878.

[21] Karthikayen, A. \& Selvakumar Raja, S. 2018, "A skellam distribution inspired trust factor-based selfish node detection technique in MANETs", Journal of Advanced Research in Dynamical and Control Systems, vol. 10, no. 13, pp. 940-949.

\section{AUTHORS PROFILE}

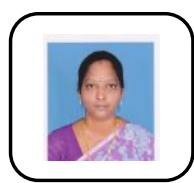

B.Kalaiselvi, Assistant Professor, Department of EIE,Bharath Institute of Higher education and research, Tamilnadu, India

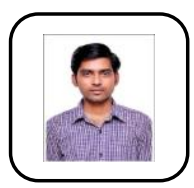

T.Vijayan, Assistant Professor, Department of EIE,Bharath Institute of Higher education and research, Tamilnadu, India.

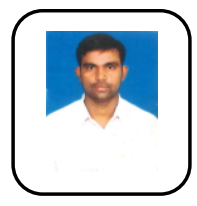

Sridhar raja D, Assistant Professor, Department of EIE,Bharath Institute of Higher education and research, Tamilnadu, India.

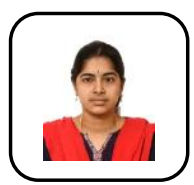

R.Abinethri, Assistant Professor, Department of EIE,Bharath Institute of Higher education and research, Tamilnadu, India 